The Society was formed as a result of an appeal from the French Comité de Vigilance des Intellectuels Antifascistes, which in January called a conference where it was decided to form an International Federation of Intellectual Workers. The bulletin in question describes the growth and activities of the British group from its original membership of fifty. The group has worked in close touch with the National Council for Civil Liberties, from which it differs chiefly in its wider concern with domestic and foreign affairs, and with various committees for the assistance of victims of Fascism and latterly with organizations to provide help for the Spanish people. It is not a party political organization and its present supporters are drawn from all shades of political opinion. It is broadly democratic and international in outlook, and by arranging for discussions among its members seeks to find the greatest measure of agreement on such questions as the need for a Popular Front or of the best way of forming it ; on the question of armaments, the League of Nations and collective security, and on the practicability of removing, by economic or political action, the causes of war. The Honorary Secretary is Margaret Gardiner, 23, Haymarket, London, S.W.1.

\section{Birth- and Death-Rates for 1936 in England}

AcCording to a return published by the RegistrarGeneral, the birth-rate in England and Wales during the year 1936 is provisionally estimated at 14.8 live births per thousand of the population, and the crude death-rate at $12 \cdot 1$ deaths per thousand of the population. The number of deaths of children under one year, per 1,000 live births, was 59. The birth-rate for 1936 is $0 \cdot 1$ above that for 1935 , and 0.4 above that of 1933, the lowest on record. The crude deathrate is 0.4 above that of 1935 and 0.7 above that of 1930 , the lowest on record. The infant mortality is 2 above that of 1935, which was the lowest on record, and is the same as that of 1934, the previous lowest on record. In 122 county boroughs and great towns of England and Wales, including London, the birthrate during 1936 is provisionally estimated at 14.9 live births per thousand of the population, the crude death-rate at $12 \cdot 3$ deaths per thousand, and the deaths of children under one year at 63 per 1,000 registered live births. The corresponding figures for the 143 smaller towns with estimated resident populations of from 25,000 to 50,000 at the 1931 census are estimated as follows: birth-rate, $15 \cdot 3$, crude death-rate $11 \cdot 7$ and infant mortality 55 . In the Administrative County of London the corresponding figures are estimated at: birth-rate, $13 \cdot 7$, crude death-rate, $12 \cdot 5$, infant mortality, 66 . These figures are provisional, and may be subject to readjustment before the publication of the Registrar-General's Statistical Review in July.

\section{Sir George Beilby Memorial Awards}

The administrators of the Beilby Memorial Fund, consisting of the presidents, treasurers and secretaries of the Institute of Chemistry, the Society of Chemical
Industry and the Institute of Metals respectively, have announced awards of a hundred guineas each to Dr. B. S. Evans and Dr. W. H. J. Vernon. Since 1919, Dr. Evans has been attached to the Research Department of Woolwich Arsenal, where he now holds the position of a scientific officer. $H_{\Theta}$ has devised numerous analytical methods for the separation and determination of metals, and contributed the chapters dealing with the methods of analysis applicable to lead, bismuth, arsenic, antimony, tin, iron, chromium and metallic constituents of steel in Mitchell's "Recent Advances in Analytical Chemistry". Dr. Vernon was appointed investigator to the newlyformed Atmospheric Corrosion Committee of the British Non-ferrous Metals Research Association in 1921. His experimental work was carried out at the Royal School of Mines, South Kensington, under Sir Harold Carpenter until 1927, when the investigation was taken over by the Department of Scientific and Industrial Research and continued at the Chemical Research Laboratory, Teddington, under Sir Gilbert Morgan. In the course of this work, which included early quantitative determinations of invisible oxide films on metals, a number of generalizations on atmospheric corrosion phenomena (ferrous and non-ferrous) has been established. Dr. Vernon's publications have included "A Bibliography of Metallic Corrosion" (Arnold), the first and second reports to the Atmospheric Corrosion Research Committee (each of which formed the subject of a general discussion by the Faraday Society) and numerous papers.

\section{Awards of the Institution of Electrical Engineers}

THE Council of the Institution of Electrical Engineers has elected Dr. Alexander Russell, principal of Faraday House Electrical Engineering College, to be an honorary member of the Institution. The Council has made the fifteenth award of the Faraday Medal to Prof. André Blondel, of Paris. The Faraday Medal is awarded by the Council of the Institution not more frequently than once a year, either for notable scientific or industrial achievement in electrical engineering or for conspicuous service rendered to the advancement of electrical science, without restriction as regards nationality, country of residence, or membership of the Institution.

\section{International Congress on the History of Science}

$\mathrm{ON}_{N}$ the occasion of the one hundred and fiftieth anniversary of the birth of Jan Evangelista Purkyner (or Purkinje), a distinguished Czech biologist, the fourth International Congress on the History of Science will be held in Prague on September 22-27. The Congress, under the presidency of Prof. Quido Vetter, will discuss papers dealing with (1) the development of the sciences during the eighteenth and first half of the nineteenth centuries; (2) the history of science in education; and (3) historical themes not included above. The contributions will not be restricted to the natural sciences only, medicine and the technical applications of science (for example, in agriculture) being also included. 